\title{
TESTING FIELD METHODS TO ASSESS INTERACTIONS BETWEEN NATIVE CADDISFLIES AND THE INVASIVE NEW ZEALAND MUDSNAIL (POTAMOPYRGUS ANTIPODARUM)
}

\author{
DANIEL GREENWOOD \\ DEPARTMENT OF ZOOLOGY AND PHYSIOLOGY \\ UNIVERSITY OF WYOMING $\uparrow$ LARAMIE, WY
}

\section{$\uparrow \quad$ AbSTRACT}

In Polecat Creek, WY, located in the Greater Yellowstone Ecosystem, the invasive New Zealand mudsnail (Potamopyrgus antipodarum) has been found to reach densities exceeding 500,000 individuals $/ \mathrm{m}^{2}$. At this extremely high density, $P$. antipodarum has been observed to consume most of the gross primary production and have a negative impact on native macroinvertebrates such as the Hydropsyche caddisfly. The current population of $P$. antipodarum in Polecat Creek has declined suggesting the population "boomed and busted"; the population was booming in 2000-2001, but in 2011 the population had decreased substantially suggesting a "bust" period for $P$. antipodarum. Native Hydropsyche caddisflies have increased dramatically in biomass during the 10year span of data, which may indicate that some native macroinvertebrates have increased in biomass due to release of suppression by $P$. antipodarum. Consequently, during my research this summer I assessed several possible methods to test suppression of Hydropsyche by $P$. antipodarum. I devised a method to collect Hydropsyche and determined whether Hydropsyche can survive in experimental chambers for use in a future field experiment. I built wooden tiles to colonize Hydropsyche out of $4 \times 4 \times 2$ inch wood blocks with $1 / 2$ inch grooves along the length of the tile. Colonization was successful with approximately two Hydropsyche collected per tile in a 24-hour period. Based on low survival of Hydropsyche within experimental chambers, the use of different experimental chambers will be necessary. Specifically, chambers that are open on the upstream side should be used to better allow a fast flow of water, which is a requirement for Hydropsyche to collect food.

\section{$\downarrow \quad$ INTRODUCTION}

Non-native species that cause ecological or economic harm are commonly referred to as invasive species (Lockwood et al. 2007). The invasive New Zealand mud snail (Potamopyrgus antipodarum) is indigenous to New Zealand and is currently considered an invasive species in Australia, Europe, and North America (Zaranko et al. 1997). Although in its native range $P$. antipodarum reproduces both asexually by parthenogenesis and sexually, in its invaded range it reproduces only parthenogenically (Alonso and Castro-Diez 2008). This means that one female snail can colonize a new stream without a mate and that all snails are clones; embryos develop into identical female offspring without fertilization.

$P$. antipodarum first invaded streams and rivers in the Greater Yellowstone Ecosystem (GYE) of Wyoming in 1994 and has since reached extremely high population densities in some invaded streams and rivers (Kerans et al. 2005, Hall et al. 2006). In my study stream, Polecat Creek WY, densities exceeding 500,000 individuals $/ \mathrm{m}^{2}$ have been documented (Hall et al. 2006). Because of its abundance in Polecat Creek, $P$. antipodarum can control fluxes of carbon and nitrogen (Hall et al. 2003), dominate the flux of nitrogen from primary producers (Hall et al. 2003), consume $75 \%$ of the gross primary production, and represent $97 \%$ of invertebrate biomass (Hall et al. 2003, 2006). P. antipodarum are primarily grazers and consume periphyton, macrophytes, and detritus (Haynes and Taylor 1984, James et al. 2000).

$P$. antipodarum may also alter the Polecat Creek ecosystem by negatively affecting native macroinvertebrate species. For example, the high 
biomass of $P$. antipodarum found in Polecat Creek nearly ceased growth of a native snail (Thon et al. in prep). In field experiments conducted in Polecat Creek, $P$. antipodarum growth also outpaced growth of a different native snail when the two species cooccurred (Riley et al. 2008). Other native taxa may also be negatively affected by $P$. antipodarum: mayflies in the genus Ephemerella overlap with $P$. antipodarum in their preferred diet (Krist and Charles 2012) and a colonization experiment in the Madison River of Yellowstone National Park showed that the number of native macroinvertebrates colonizing experimental tiles decreased with increasing $P$. antipodarum abundance (Kerans et al. 2005). Taken together, these negative effects of $P$. antipodarum on individual taxa, along with their consumption of up to $75 \%$ of gross primary production (Hall et al. 2003), suggest the possibility of widespread resource competition between $P$. antipodarum and native macroinvertebrates.

The abundance of $P$. antipodarum in Polecat Creek has significantly decreased since 2001 (Thon et al. in prep.). This severe decline may represent a population that has "boomed and busted": a population that reached high abundance (boom) followed by a sharp decline in abundance (bust). Moore et al. (2012) documented a boom and bust of $P$. antipodarum in the Upper Owens River, California. Moore and colleagues (2012) collected data over a 10-year period from the beginning of a $P$. antipodarum invasion and through the population bust. Immediately following the invasion of $P$. antipodarum, native grazing invertebrates decreased in abundance by $80 \%$ and then doubled in abundance after $P$. antipodarum abundance declined (Moore et al. 2012). Because P. antipodarum affects community structure (Moore et al. 2012) and ecosystem processes (Hall et al. 2003), its decline in Polecat Creek will also likely cause changes in the macroinvertebrate community. In support of this prediction, Thon et al. (in prep.) found that the decrease in P. antipodarum biomass from 2001-2009 coincided with an increase in biomass of a native snail species (Fossaria sp.) in Polecat Creek.

By comparing 2000-2001 and 2011 data, I have identified several native invertebrate taxa that were likely suppressed by $P$. antipodarum during the boom period (their abundance has increased greatly since the bust of $P$. antipodarum). Of those taxa, Hydropsyche caddisflies showed one of the greatest increases in abundance. In preparation for performing field experiments to elucidate the mechanisms by which $P$. antipodarum suppresses Hydropsyche caddisflies, I tested one method of collecting Hydropsyche and determined whether these caddisflies can survive inside experimental chambers.

\section{$\uparrow \quad$ METHODS}

\section{Hydropsyche collection}

Hydropsyche caddisfly larvae spin silk nets, which they use to collect and gather food. To take advantage of this behavior, I constructed colonization tiles from $4 \times 4 \times 2$ inch wooden blocks. I used a circular power saw to cut $1 / 2 \times 1$ inch grooves down the length of the topside of the tile (Figure 1). I attached collection tiles to bricks to anchor them to the stream substrate (Figure 2). I left 12 tiles in Polecat Creek for 24 hours to assess whether Hydropsyche caddisflies would colonize the tiles.

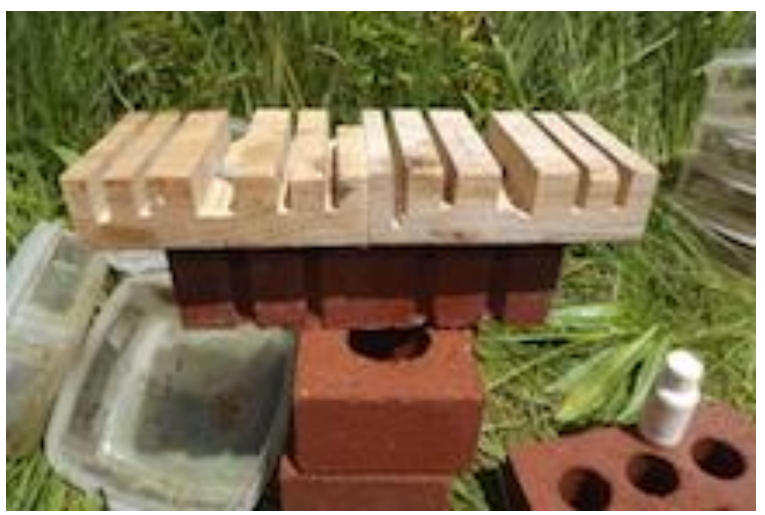

Figure 1. Two Hydropsyche collection tiles attached to a brick.

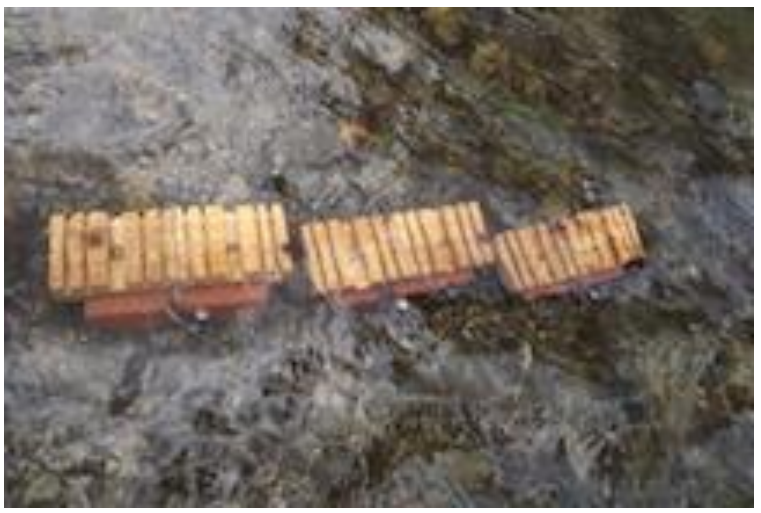

Figure 2. Six Hydropsyche collection tiles placed in Polecat Creek.

\section{Hydropsyche survival}

In a future experiment, I plan to house Hydropsyche caddisflies and the invasive $P$. antipodarum together in experimental chambers. For the experimental chambers, I will use modified, square plastic sandwich containers $\left(156.3 \mathrm{~cm}^{2}\right)$ with mesh $(600-\mu \mathrm{m})$ windows on the top and sides to keep invertebrates in the chamber and allow fresh, oxygenated water to flow through the chamber (Figure 3). To determine the efficacy of these chambers, I 


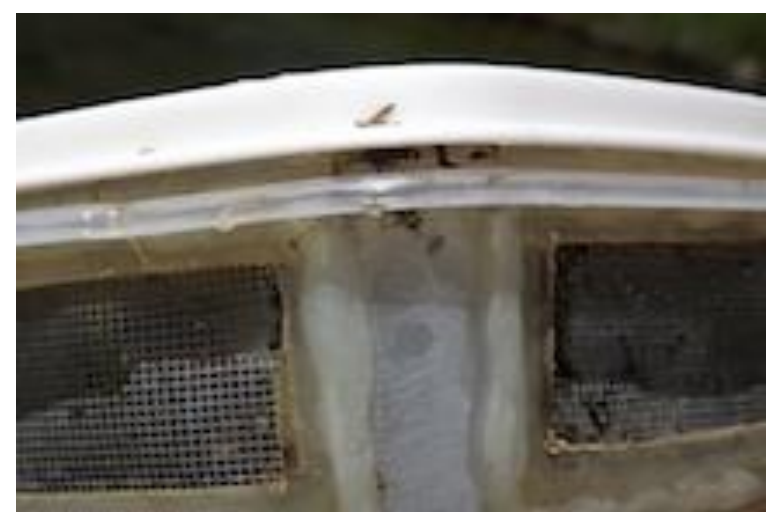

Figure 3. Modified sandwich container used as an experimental chamber.

wanted to know if Hydropsyche could survive in them for a duration of 5-7 days.

I placed 12 collection tiles, containing 1-3 colonized Hydropsyche caddisflies (29 larvae total), into experimental chambers and anchored them to bricks (Figure 4). I recorded the number and position of caddisfly larvae on the tiles before closing the chamber. I left the chambers in Polecat Creek and recorded the number of caddisfly larvae present within the chambers after seven days.

In a separate experiment, I placed six chambers in Polecat Creek as described above (13 larvae total). I also placed five colonized tiles in the creek without housing them inside chambers to determine if the chambers affected survival of larvae (12 larvae total). After five days, I recorded the number of larvae present on tiles of both treatments, ignoring new colonizations on tiles outside of chambers.

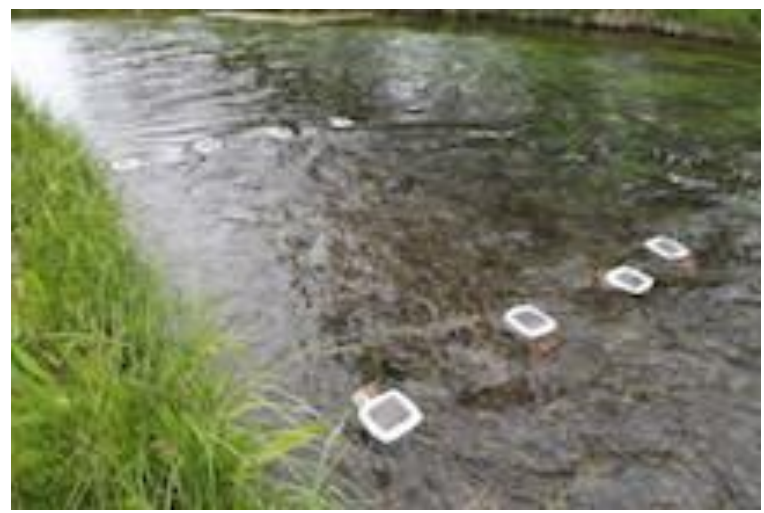

Figure 4. Eight Hydropsyche collection tiles within anchored experimental chambers.

\section{$\downarrow \quad$ RESULTS}

\section{Hydropsyche collection}

Hydropsyche collection was successful After 24 hours in Polecat Creek, a total of 29 Hydropsyche larvae colonized the 12 collection tiles. All tiles were colonized by larvae with a minimum of one and a maximum of three larvae per tile (Figure 5).

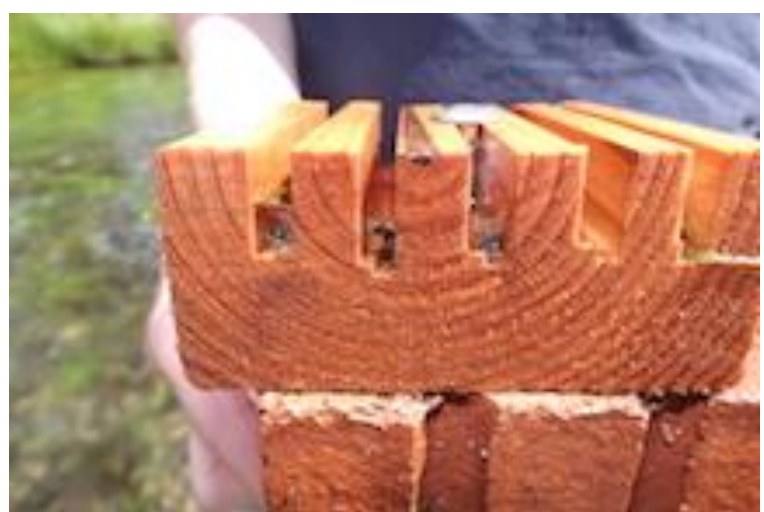

Figure 5. Hydropsyche collection tile with three colonized caddisflies.

\section{Hydropsyche survival}

For the first experiment, after seven days in Polecat Creek, a total of 7 of 29 Hydropsyche larvae were present within the 12 experimental chambers (21.4\%). In the second experiment, after five days in the creek, 4 of 13 larvae were present in the six chambers $(30.8 \%)$. Five tiles not contained in chambers contained 11 of 12 larvae after five days in the creek $(91.7 \%)$.

\section{$\uparrow \quad$ Discussion}

The Hydropsyche collection tiles performed above expectation. In 24 hours I collected 29 Hydropsyche larvae. Importantly, the tiles were colonized only by the target taxa, making separation of Hydropsyche from other taxa unnecessary.

Survival of Hydropsyche larvae within the experimental chambers was low (21-30\%). These percentages represent larvae present, however, and may not have resulted from death, but departure of larvae from the chambers. The mesh size on the chamber windows was large enough for larvae to escape and larvae may have migrated out of the chambers due to undesirable conditions. Because Hydropsyche larvae require a fast flow of water in order to collect food in their nets, reduced flow from the chamber mesh may have caused larvae to migrate out of the chamber in search of better flow conditions. 
In contrast, tiles that remained outside of chambers contained $\sim 90 \%$ of the original larvae present. These results indicate that the experimental chambers used in future experiments must be modified. Accordingly, I will remove the mesh from the upstream side of the chambers to allow faster flow of water through the chamber. Escape from the open side of the chamber is unlikely since a large portion of larvae remained on tiles even when left in open water.

\section{$\uparrow \quad$ ACKNOWLEDGEMENTS}

I would like to thank director Harold Bergman and all the staff at the UW-NPS research station for providing tools and supplies for the construction of Hydropsyche collection tiles used during this research. I thank my field assistant, Meghan Bochanski and Wyoming EPSCoR for funding her summer research. I also thank my adviser, Amy Krist, and her colleague, Teresa Tibbets, for their valuable advice when designing my experiments.

\section{$\uparrow \quad$ Literature Cited}

Alonso, A., and P. Castro-Diez. 2008. What explains the invading success of the aquatic mud snail Potamopyrgus antipodarum (Hydrobiidae, Mollusca)? Hydrobiologia 614:107-116.

Hall Jr, R. O., M. F. Dybdahl, and M. C. VanderLoop. 2006. Extremely high secondary production of introduced snails in rivers. Ecological Applications 16:1121-1131.

Hall Jr, R. O., J. L. Tank, and M. F. Dybdahl. 2003. Exotic snails dominate nitrogen and carbon cycling in a highly productive stream. Frontiers in Ecology and the Environment 1:407-411.

Haynes, A., and B. J. R. Taylor. 1984. Food finding and food preference in Potamopyrgus jenkinsi (EA Smith) (Gastropoda: Prosobranchia). Archiv für Hydrobiologie 100:479-491.
James, M. R., I. Hawes, M. Weatherhead, C. Stanger, and M. Gibbs. 2000. Carbon flow in the littoral food web of an oligotrophic lake. Hydrobiologia 441:93-106.

Kerans, B. L., M. F. Dybdahl, M. M. Gangloff, and J. E. Jannot. 2005. Potamopyrgus antipodarum: Distribution, density, and effects on native macroinvertebrate assemblages in the Greater Yellowstone Ecosystem. Journal of the North American Benthological Society 24:123-138.

Krist, A. C., and C. C. Charles. 2012. The invasive New Zealand mudsnail, Potamopyrgus antipodarum, is an effective grazer of algae and altered the assemblage of diatoms more than native grazers. Hydrobiologia 694:143151.

Lockwood, J. L., M. F. Hoopes, and M. P. Marchetti. 2013. Invasion ecology. John Wiley \& Sons.

Moore, J. W., D. B. Herbst, W. N. Heady, and S. M. Carlson. 2012. Stream community and ecosystem responses to the boom and bust of an invading snail. Biological Invasions 14:2435- 2446.

Riley, L. A., M. F. Dybdahl, and R. O. Hall Jr. 2008. Invasive species impact: Asymmetric interactions between invasive and endemic freshwater snails. Journal of the North American Benthological Society 27:509520.

Thon, H.N., M.D. Larson, R. O. Hall Jr., and A.C. Krist. In prep. Invasive and native species interactions: Growth of a native snail is nearly halted by high levels of biomass produced by the invasive New Zealand mudsnail.

Zaranko, D. T., D. G. Farara, and F. G. Thompson. 1997. Another exotic mollusk in the laurentian great lakes: The New Zealand native Potamopyrgus antipodarum (Gray 1843) (Gastropoda, Hydrobiidae). Canadian Journal of Fisheries and Aquatic Sciences 54:809-814. 